\title{
Effect of different fattening methods on slaughter and carcass characteristics of Tuj male lambs
}

\author{
Mehmet Sarı', Ali Rıza Aksoy', Muammer Tilki', İsmail Kaya² and Serpil Işık' \\ 'Department of Animal Science, Faculty of Veterinary Medicine, University of Kafkas, Kars, Turkey, ${ }^{2}$ Department of \\ Animal Nutrition, Faculty of Veterinary Medicine, University of Ondokuz Mayis, Samsun, Turkey
}

\begin{abstract}
This study was conducted to determine effect of different fattening methods on slaughter and carcass characteristics of Tuj male lambs. Tuj lambs $(n=18)$ were used in three groups with six lambs in each group. Group 1 was only grazed on the pasture and group 2 was supplemented $200 \mathrm{~g}$ concentrate with the pasture. Group 3 was supplemented $400 \mathrm{~g}$ concentrate with the pasture. Lambs were grazed on the pasture for $8 \mathrm{~h}$ /day. Concentrate with $18.5 \% \mathrm{CP}$ and 2650 $\mathrm{kcal} / \mathrm{kg} \mathrm{ME}$ was fed to lambs in addition to pasture. At the end of three months of experiment, the lambs were slaughter and carcass characteristics and carcass measurements were evaluated. Slaughter weights of group 1,2 and 3 were $44.10,44.86$ and $46.00 \mathrm{~kg}$, respectively, and hot carcass weights were $20.66,21.36$ and $22.15 \mathrm{~kg}$, respectively, hot dressing percentage $46.85,47.56$ and $47.64 \%$, respectively. The differences between groups of slaughter and carcass characteristics and carcass measurements of lambs were not statistically significant $(P>0.05)$. As a conclusion, supplementations of concentrate feed to grazing lambs on the pasture were no effect on slaughter and carcass characteristics and carcass measurement in lambs.
\end{abstract}

Keywords: Tuj lamb, pasture, slaughter and carcass characteristics

\section{Introduction}

Approximately $95.8 \%$ of Turkey's sheep population (21 749508 heads) are native breeds. Sheep meat (135687 t) is an important to red meat production amounting to $17.37 \%$ of the total meat production (780718 t) of Turkey. Tuj makes up $0.3 \%$ of the Turkish sheep population. There are 350969 heads of sheep in Kars, 1/7 of which is Tuj breed (Anonymous 2005, Tuik 2011). The Tuj breed is raised in throughout the north-east of Turkey generally for meat production. Breeders are not normally willing for expenses of any supplementation and almost never use supplement but hay. Therefore, performance of the lambs depends on the pasture and hay. In order to increase the proportion of lambs that reach appropriate weights at sale, supplementary feed could be provided (Saatci et al. 2003).

The production of meat in Turkey is principally based on the use of grass pasture and forage as the most economic feed ingredient. The use of these sources is limited due to the seasonal fluctuation of nutritive value in grass, nutritional stress and low animal productivity. Meat production also is influenced of breed, age, sex and some environmental factors. Insufficient feeding is among the most important environmental factors that giving rise to 
low yield (Yilmaz et al. 2007). Therefore; different fattening methods are used for improve of meat yield and quality in lambs. Supplementary feeding can have an important influence on the growth and development of weaned lambs (Francis et al. 2000). Soder et al. (1995), Elicin et al. (1988), Macit et al. (2003) and Saatci et al. (2003) found the use of supplementary concentrate on Tuj lambs during grazing season to increase slaughter and carcass weight. Positive effect of supplementary barley on Morkaraman lambs in terms of body and carcass weight reported by Bolat et al. (1995).

The aim of this study was to determine the effect of different fattening methods on slaughter and carcass characteristics and measurements of Tuj male lambs based on pasture, supplementation of pasture +200 and pasture $+400 \mathrm{~g}$ concentrate.

\section{Material and methods}

This experiment was conducted at the Application and Research Farm of the Faculty of Veterinary Medicine, Kafkas University in Kars, Turkey. All lambs were single born from dams aged 3-5 years. Lambs suckled their dams and grazed on pasture with no additional feed until 3 months of age. At the age of 3 months, Tuj lambs $(n=18)$ were divided into 3 groups with 6 lambs in each one. Group 1: only pasture grass; Group 2: pasture grass and $200 \mathrm{~g}$ per day of commercial feed concentrate with $18.5 \% \mathrm{CP}$ and $2650 \mathrm{kcal} / \mathrm{kg} \mathrm{ME}$; and Group 3: pasture grass and $400 \mathrm{~g}$ per day of commercial feed concentrate with $18.5 \% \mathrm{CP}$ and $2650 \mathrm{kcal} / \mathrm{kg}$ ME. Lambs were grazed on the pasture $8 \mathrm{~h}$ in a day and water was offered to the animals $\mathrm{ad}$ libitum. The experiment was finished at the end of 3 months.

Pre-slaughter live weight was recorded after $12 \mathrm{~h}$ fasting with free access to water. The lambs were weighed in a scale with an accuracy of $1 \mathrm{~g}$. After the slaughtering the lambs, skin, head, feet, spleen, gastrointestinal tract, and testicles were removed. Then, hot carcass weights were determined and dissected into parts according to Akcapinar (1981) namely, leg, loin, back, forearm, chuck-neck, tail and the remaining. Carcass length I and II and chest circumference were measured on the carcass as described by Ariturk (1983).

In order to determine the effect of different fattening methods on slaughter and carcass characteristics and measurements, variance analysis method was employed using SPPS 12.0 statistical package software (SAS Institute Inc., Cary, NC, USA). Duncan multiple range tests were used to evaluate the significance of the difference among the groups.

\section{Results}

The slaughter and carcass characteristics of lambs in the groups are given in Table 1. The differences among the groups in slaughter weights $(44.10,44.86$ and $46.00 \mathrm{~kg}$, respectively), hot carcass weights $(20.66,21.36$ and $22.15 \mathrm{~kg}$, respectively) and hot dressing percentage (46.85, 47.56 and $47.64 \%$, respectively) were not significant $(P>0.05)$.

Leg weights of group 1, 2 and 3 were $6.29,6.36$ and $6.47 \mathrm{~kg}$, loin weights were $1.54,1.59$ and $1.68 \mathrm{~kg}$, back weights were $1.61,1.65$ and $1.61 \mathrm{~kg}$, forearm weights were $3.51,3.66$ and $3.75 \mathrm{~kg}$, chuck-neck weights $1.52,1.55$ and $1.66 \mathrm{~kg}$, remaining weights were $3.30,3.36$ and $3.57 \mathrm{~kg}$, tail weights $2.56,2.83$ and $2.91 \mathrm{~kg}$, kidney weights were $0.16,0.16$ and $0.18 \mathrm{~kg}$ and kidney fat weights $0.15,0.16$ and $0.18 \mathrm{~kg}$, respectively. The differences among the groups in these characteristics was not found to be statistically significant $(P>0.05)$. 
Table 1

Slaughter and carcass characteristics of lambs in the groups

\begin{tabular}{lccccc}
\hline Characteristics & Group 1 & Group 2 & Group 3 & Overall & Significance \\
\hline Slaughter weight, $\mathrm{kg}$ & $44.10 \pm 1.75$ & $44.86 \pm 1.41$ & $46.00 \pm 1.69$ & $45.11 \pm 0.91$ & $\mathrm{~ns}$ \\
Hot carcass weight, kg & $20.66 \pm 0.83$ & $21.36 \pm 0.87$ & $22.15 \pm 1.12$ & $21.39 \pm 0.53$ & $\mathrm{~ns}$ \\
Hot dressing percentage, \% & $46.85 \pm 0.28$ & $47.56 \pm 0.47$ & $47.64 \pm 0.89$ & $47.35 \pm 0.33$ & $\mathrm{~ns}$ \\
Leg weight, $\mathrm{kg}$ & $6.29 \pm 0.14$ & $6.36 \pm 0.16$ & $6.47 \pm 0.25$ & $6.37 \pm 0.10$ & $\mathrm{~ns}$ \\
Loin weight, $\mathrm{kg}$ & $1.54 \pm 0.09$ & $1.59 \pm 0.10$ & $1.68 \pm 0.11$ & $1.60 \pm 0.05$ & $\mathrm{~ns}$ \\
Back weight, $\mathrm{kg}$ & $1.61 \pm 0.06$ & $1.65 \pm 1.13$ & $1.61 \pm 0.06$ & $1.66 \pm 0.06$ & $\mathrm{~ns}$ \\
Forearm weight, $\mathrm{kg}$ & $3.51 \pm 0.12$ & $3.66 \pm 0.15$ & $3.75 \pm 0.19$ & $3.64 \pm 0.08$ & $\mathrm{~ns}$ \\
Chuck-neck weight, $\mathrm{kg}$ & $1.52 \pm 0.08$ & $1.55 \pm 0.08$ & $1.66 \pm 0.09$ & $1.58 \pm 0.05$ & $\mathrm{~ns}$ \\
Remaining weight, kg & $3.30 \pm 0.20$ & $3.36 \pm 0.17$ & $3.57 \pm 0.21$ & $3.41 \pm 0.11$ & $\mathrm{~ns}$ \\
Tail weight, $\mathrm{kg}$ & $2.56 \pm 0.20$ & $2.83 \pm 0.16$ & $2.91 \pm 0.14$ & $2.77 \pm 0.10$ & $\mathrm{~ns}$ \\
Kidney weight, $\mathrm{kg}$ & $0.16 \pm 0.01$ & $0.16 \pm 0.01$ & $0.18 \pm 0.01$ & $0.16 \pm 0.01$ & $\mathrm{~ns}$ \\
Kidney fat weight, $\mathrm{kg}$ & $0.15 \pm 0.01$ & $0.16 \pm 0.01$ & $0.18 \pm 0.01$ & $0.16 \pm 0.01$ & $\mathrm{~ns}$ \\
Carcass length $\mathrm{I}, \mathrm{cm}$ & $81.00 \pm 15.40$ & $78.67 \pm 17.69$ & $109.50 \pm 18.76$ & $89.72 \pm 10.00$ & $\mathrm{~ns}$ \\
Carcass length $\mathrm{Il}, \mathrm{cm}$ & $70.33 \pm 2.94$ & $69.33 \pm 5.47$ & $76.50 \pm 5.78$ & $72.06 \pm 2.76$ & $\mathrm{~ns}$ \\
Chest circumference, $\mathrm{cm}$ & $78.17 \pm 1.53$ & $78.50 \pm 0.71$ & $79.17 \pm 0.98$ & $78.61 \pm 0.62$ & $\mathrm{~ns}$ \\
\hline
\end{tabular}

ns: not significant $(P>0.05)$

In Table 1, the means of carcass length I, carcass length II and chest circumference of lambs in the groups are presented. Carcass length I of group 1, 2 and 3 were $81.00,78.67$ and $109.50 \mathrm{~cm}$, carcass length II were $70.33,69.33$ and $76.50 \mathrm{~cm}$, chest circumference were $78.17,78.50$ and $79.17 \mathrm{~cm}$, respectively. The differences among the groups in carcass length I, carcass length II and chest circumference of lambs were not statistically significant $(P>0.05)$.

\section{Discussion}

There are few studies with effect of different fattening methods on slaughter and carcass characteristics of Tuj male lambs. Slaughter weights of Group 1, 2 and 3 were 44.10, 44.86 and $46.00 \mathrm{~kg}$, respectively. The differences among the groups in slaughter weights was not significant $(P>0.05)$. The slaughter weights of Group 1, 2 and 3 found in this study were higher than those reported by Kirmizibayrak et al. (2003) and Macit et al. (2002) for Tuj male lambs raised in semi intensive conditions. These results were also higher than the values reported by Saatci et al. (2003) for Tuj lambs in Group T, Group TC and Group C.

Hot carcass weights of group 1, 2 and 3 were 20.66, 21.36 and $22.15 \mathrm{~kg}$, respectively. The hot carcass weights of three groups in this study higher than those reported by Elicin et al. (1988) reporting a range of $14.83-19.60$ for Tuj lambs feed pasture, pasture $+500 \mathrm{~g}$ and intensive concentrate, and reported by Ulusan et al. (1996) reporting a hot carcass weight of $13.9 \mathrm{~kg}$ for Tuj male lambs feed on pasture.

The hot dressing percentages in this study of $46.85,47.56$ and $47.64 \%$ for lambs in three groups are similar with the findings of Macit et al. (2003) reporting a hot dressing percentage of $49.09 \%$ for Tuj male lambs raised in semi intensive conditions, and Geliyi et al. (1984) who reported a range of $45.23-46.33 \%$ for Tuj male lambs fed on different roughage rates.

There was no differences among the groups in terms of leg, loin, back, forearm, chuckneck, remaining, tail, kidney and kidney fat weight $(P>0.05)$. The leg, loin and forearm weights of Group 1 and 2 found in this study were higher than those reported by Saatci et al. 
(2003) for Tuj lambs in Group T and Group TC. In the present study, the leg and loin weights of Group 3 found to be similar reported by Saatci et al. (2003) for Tuj lambs in Group C. The same weight values of legs were found to be higher than those reported by Elicin et al. (1988) for Tuj lambs fed by pasture, pasture $+500 \mathrm{~g}$ and intensive concentrate. Ulusan et al. (1996) and Kirmizibayrak et al. (2003) also reported the similar findings. The weights of tail fat in all three groups in this study were lower than those reported by Geliyi et al. (1984), Aksoy (1995) and Saatci et al. (2003), but this values were higher than the results reported by Ulusan et al. (1996) and Macit et al. (2002) for Tuj lambs.

In the present study, the differences among the groups in carcass measurements was not statistically significant $(P>0.05)$. The carcass length I and II and chest circumference values obtained in the study were found to be higher than the values reported by Ulusan et al. (1996) for Tuj lambs. Again, the chest circumference in this study were found to be higher than the values reported by Teke \& Unal (2009) for Akkaraman, Morkaraman and Turkish Merino lambs. However, the chest circumference was found to be lower than the values reported by Aksoy (1995) for Tuj lambs. The differences between this study and other studies with regards to slaughter and carcass characteristics and certain carcass measurements might be due to maternal age, fattening age, fattening duration and slaughter age, the difference on feeding methods, quality of pasture, and the use of different breeds of lambs.

In this study, the differences between groups of slaughter and carcass characteristics and measurements were not statistically significant. The results of this study suggest that a feeding system based on grazing might be appropriate for fattening male Tuj lambs since improvements in slaughter and carcass characteristics and measurements were achieved. Therefore, findings of this study recommends that a feeding system based on grazing might be appropriate for Tuj male lambs weaned at 2-3 months of age in North Eastern Turkey. This situation may be better when high quality of pasture was used.

\section{References}

Akcapinar H (1981) Researches on the meat production and carcass characteristics of Daglic, Akkaraman and Kivircik lambs slaughtered at different slaughter weights. FU Vet Fak Derg 6, 165-184

Aksoy AR (1995) [Fattening performance, slaughtering and carcass characteristics of Morkaraman and Tushin ram lambs at different slaughtering]. Ankara Univ Vet Fak Derg 42, 15-23 [in Turkish]

Anonymous (2005) Presence of land and the structure of the land in the province of Kars. http://www. karstarim.gov.tr/tarimsalyapi.asp [last accessed 12.09.2012]

Ariturk E (1983) [General Zootechny]. Univ Ankara, Faculty of Veterinary Science Publications, Publication No. 395, 247-249 [in Turkish]

Bolat D, Deniz S, Baytok E, Oguz MN, Gul M (1995) [Effect of various amount of barley on fattening performance and carcass characteristics in grazing lambs]. Hay Aras Derg 5, 41-45 [in Turkish]

Elicin A, Geliyi C, Ertugrul M, Cengiz F, llaslan M, Askın Y (1988) [Fattening performance and carcass parameters in lambs fed various methods]. Ankara Univ Zir Fak Yil 39, 323-333 [in Turkish]

Francis SM, Littlejohn RP, Stuart SK, Veenvliet BA, Suttie JM (2000) The effect of restricted feeding on growth hormone (GH) secretory patterns in genetically lean and fat wether lambs. Anim Sci 70, 425-433

Geliyi C, Cakir A, Ilaslan M, Ulker K (1984) [Fattening performance and carcass characteristics of Tuj, Merino and Tuj $\times$ Merino crosses fed on different roughage rates. II. Slaughter and carcass characteristics]. Kars Deneme ve Üretme İstasyonu no. 12 [in Turkish] 
Kirmizibayrak T, Saatci M, Aksoy AR (2003) Slaughter and carcass characteristics of Tushin and Red Karaman lambs raised in semi intensive conditions. Kafkas Univ Vet Fak Derg 9, 75-78

Macit M, Esenbuga N, Karaoglu M (2002) Growth performance and carcass characteristics of Awassi, Morkaraman and Tushin lambs grazed on pasture and supported with concentrate. Small Rumin Res 44, 241-246

Macit M, Sahin S, Esenbuga N, Karaoglu M (2003) Growth and carcass characteristics of three fat-tailed pure breeds under grazing with concentrate supplementation. Turk J Vet Anim Sci 27, 331-337

Saatci M, Yildiz S, Kaya I (2003) New rearing systems for Tuj (Tushin) lambs. Small Rumin Res 50, 23-27

Soder KJ, Thomas VM, Kott RW, Hatfield PG, Olson B (1995) Influence of energy or protein supplementation during midpregnancy on forage intake of ewes grazing Montana winter range. J Anim Sci 73, 2853-2859

Teke B, Unal N (2009) The effects of slaughter weight and sex on some slaughter traits of Akkaraman and Morkaraman and Turkish Merino lambs. Ankara Univ Vet Fak Derg 56, 289-164

Tuik (=Turkish Statistical Institute) (2011) Livestock statistics. http://www.tuik.gov.tr/VeriBilgi.do?tb_id=46\& ust_id=13. [last accessed 27.12.2011]

Ulusan HOK, Aksoy AR, Uzun N, Karabulak C, Lacin E (1996) [Slaughter and carcass traits of Morkaraman, Tuj and their crosses (Morkaraman $\times$ Tuj) male lambs fed on natural pasture]. Kafkas Univ Vet Fak Derg 2, 28-33 [in Turkish]

Yilmaz O, Denek H, Bayram D (2007) Effects of lambing season, sex and birth type on growth performance in Norduz lambs. Small Rumin Res 68, 336-339

Received 26 October 2011, accepted 21 April 2012.

Corresponding author:

Mehmet Sari

email: msari_40@hotmail.com

Department of Animal Science, Faculty of Veterinary Medicine, University of Kafkas, 36300 Kars, Turkey 